\title{
Ultrasonic Measurements In Brazilian Hardwood
}

\author{
Fabiana Goia R. de Oliveira ${ }^{a}$, Janaína Anadia O. de Campos ${ }^{a}$, Almir Sales $^{b_{*}}$ \\ ${ }^{a}$ São Carlos Institute of Physics, University of São Paulo - USP, São Carlos - SP, Brazil \\ ${ }^{\mathrm{b}}$ Department of Civil Engineering, Federal University of São Carlos - UFSCar
}

São Carlos - SP, Brazil

Received: November 25, 2000; Revised: September 25, 2001

\begin{abstract}
This paper reports on a study of the application of ultrasound waves in wood with the purpose of evaluating the latter's mechanical properties. The evaluation is based on the correlation between the speed of sound, modulus of elasticity and density. The speed of transmission is sensitive to the material's quality-determining factors; hence, this technique is an important industrial tool to improve the quality control of processes. The species used in the experimental procedure were "cupiúba" (Goupia glabra) and "jatobá" (Hymenaea sp). Tests were carried out to determine the properties of apparent density at $12 \%$ humidity content $\left(\rho_{\mathrm{ap}, 12 \%}\right)$, modulus of elasticity in static deflection ( $\left.E_{M}\right)$, and modulus of rupture (MOR). Ultrasound tests were also performed to find the stiffness matrix coefficient $\left(\mathrm{C}_{\mathrm{LL}}\right)$, for purposes of comparison with the static findings. The results and analyses lead us to conclude that the nondestructive ultrasound method can be employed to obtain reliable evaluations of the mechanical properties of dicotyledons.
\end{abstract}

Keywords: ultrasound, dicotyledons, nondestructive evaluation

\section{Introduction}

Technological advances have allowed for better use to be made of the properties of wood and its by-products, creating new products and broadening the scope of their application, thus rendering wood an even more versatile and widely employed material than it was in the past. One of the highlights of these technological advances is the ultrasound wood evaluation technique, an important tool with the potential to improve this material's quality and competitiveness.

The use of ultrasonic wave propagation as a nondestructive evaluation technique has proved to be a viable method to characterize wood. Research on ultrasound techniques has evidenced the efficacy of the method to determine the mechanical properties of wood ${ }^{2}$. The validity of this technique is tested by means of comparisons with results obtained through destructive tests, providing significant correlation parameters.

The advantages of the ultrasound technique over the conventional characterization methods are its speed, versatility and lower $\operatorname{cost}^{13}$. Another advantage is the fact that the material is unaffected by the propagation phenomenon, allowing the sample to be tested a number of times without becoming deformed.

*e-mail: almir@power.com.br
Another application of the nondestructive methods is the evaluation of structures that are in use, i.e., in loco evaluation, allowing for their maintenance or rehabilitation through a mapping of the deteriorated areas, which permits evaluations to be made of their structural integrity without the need to remove part of the structure.

Determination of the mechanical properties of wood by ultrasonic propagation is based on the correlation between the speed of sound, the modulus of elasticity and the density.

The application and measurement consists of positioning two accelerometer transducers on the material to be evaluated. The ultrasonic wave is introduced into the material by one of the transducers and picked up by the other transducer, with the time reading - in microseconds - performed by the ultrasound instrument itself. The recorded times are used to calculate the coefficient of the stiffness matrix, based on Eq. 1 .

$$
C_{L L}=\rho \times v^{2} \times 10^{-6}
$$

with

$$
\mathrm{v}=\mathrm{d} / \mathrm{t}
$$


where:

$\mathrm{C}_{\mathrm{LL}}$ - coefficient of the stiffness matrix (MPa);

$\mathrm{r}$ - density of the wood $\left(\mathrm{kg} / \mathrm{m}^{3}\right)$;

$\mathrm{v}$ - velocity of the longitudinal wave $(\mathrm{m} / \mathrm{s})$;

$\mathrm{d}$ - distance traveled by the wave $(\mathrm{m})$;

$\mathrm{t}$ - time elapsed along the way (s).

Many variables significantly influence the propagation of ultrasonic waves in wood, particularly considering its microstructural characteristics and chemical composition. Therefore, the variability of some of these characteristics must be preestablished in order to facilitate the understanding of the others. It should also be noted that these differences might vary depending on whether the species involved are conifers or dicotyledons, and according to the conditions of soil and climate in which the wood developed. From this standpoint, it can be stated that the velocity of wave propagation.

Is greater in the longitudinal (propagation through the fibers) than in the radial direction (propagation through the rays), and that it is even slower in the tangential direction ${ }^{4,6}$ (disoriented propagation);

It is greater the longer the length of the fibers ${ }^{3,6}$;

It is slower the greater the porosity and permeability of the cell wall, assuming the density is constant in the direction considered ${ }^{3,7}$;

It is greater the greater the density in any of the three directions of the wood, considering a constant humidity content throughout the sample $\mathrm{e}^{4,5}$;

It is greater the greater the continuity of crystalline regions in the cell wall (higher occurrence of cellulose than of lignin and hemicellulose), decreasing as amorphous regions increase (greater presence of lignin and hemicellulose than of cellulose $)^{5,10}$.

Photosynthesis favors the occurrence of polymerization reactions that originate sugars, which form the constituent substances of the anatomical structure of plants. The most important of these substances are cellulose, hemicellulose and lignin ${ }^{8,16}$.

Cellulose is a hygroscopic polysaccharide nonsoluble in water, which constitutes from 45 to $60 \%$ of the substances of wood, and is the principal forming component of the walls of the fibers, veins and tracheids. This polysaccharide can be characterized by crystalline regions and small amorphous zones. Cellulose molecules rarely occur as individual entities in the cell wall; rather, they are situated in bundles called elementary fibrils. Each elementary fibril contains a parallel arrangement of 50 to 80 cellulose molecules, all predominantly aligned. The mean values $^{3,14}$ found for the degree of polymerization (DP) of cellulose range from 1000 to 15000 .

The term hemicellulose refers to a mixture of low molecular mass polysaccharide polymers that are associ- ated with the cellulose in plant tissue, corresponding to 15 to $25 \%$ of the wood's chemical composition. It is an amorphous polymer comprising a central chain from which lateral chains branch out. In addition to acting as a matrix in which the cellulose chains are immersed, hemicellulose is the most hygroscopic component of the cell walls. Considering pentosans and hexosans as its main polymer formers, a mean value of 50 to 200 can be attributed to the degree of polymerization of hemicellulose $e^{9,11}$.

Lignin is a complex, amorphous three-dimensional polymer that contributes toward cell formation, acting as an adhesive and strengthening the cell walls to resist mechanical loads. Covalent intramolecular links and intermolecular Van der Waal links determine the arrangement of the cellulosic crystals, which are immersed in the lignin matrix and have a diameter of $35 \AA$. Fibril aggregates form microfibrils with $200 \AA$ diameters. As the complexity of the lignin system increases, microfibrils are aggregated into macrofibrils, which are the constructive base that comprises the various levels of the cell wall. Considering the molecular mass of phenylpropane (the forming unit of lignin), the degree of polymerization of isolated lignins lies $^{5,20}$ in a range of 5 to 60 .

Cellulose microfibrils are usually arranged in a typical parallel model and slanted in relation to the cells' axis, generally corresponding to the vertical direction of the tree's growth. In this direction (longitudinal) there is a greater continuity of crystalline regions, with a more frequent occurrence of cellulose. Thus, the velocity of wave propagation is greater in the longitudinal direction owing to the cells' orientation along this axis, offering a continuous path for the waves. For a wave to propagate in the radial direction, it would have to cross layers of lignin and hemicellulose to reach the cellulose, resulting in its attenuation due to the amorphous and inelastic regions of these compounds. The lowest velocities occur in the tangential direction, in which the waves propagate through regions with larger amounts of lignin and hemicellulose and are, thus, subjected to significant attenuation ${ }^{4,5,12}$.

The differing degrees of polymerization of the main constituents of the cell was also corroborate the above statements, i.e., the higher the mean value of the DP, the greater the continuity of elastic and crystalline material. Thus, the wave propagates with greater speed in the cellulose layers (DP of 1000 to 15000) than in the hemicellulose layers (DP of 50 to 200), with the lowest velocity occurring when it passes through lignin layers (DP of 5 to 60$)^{7,15,19}$.

When the content of humidity is constant throughout a sample, increases in density generally lead to higher wave propagation speeds in any of the three orientations of the wood. The reliability of the estimate of the modulus of elasticity, using the ultrasound techniques, increases with 
the use of samples with higher density and lower humidity content. This is due, in both cases, to the greater rigidity of the material, which favors the propagation of elastic waves ${ }^{17}$.

In regard to fiber length, it can be stated that the longer the fibers the greater the speed of wave propagation. As stated earlier, this is due to the greater continuity of crystalline and elastic material in the longitudinal direction and explains the occurrence of higher wave propagation speeds in conifers than in dicotyledons for samples with constant humidity contents, even with the predominance of apparently lower densities in conifers in relation to leafy species. It should also be noted that dicotyledons are more anisotropic owing to the greater complexity of their woody composition, which favors the dissipation of the wave ${ }^{5,21}$.

The purpose of this study is to analyze the reliability of ultrasound in the evaluation of wood by comparing the results obtained against the values determined by destructive tests.

\section{Experimental Procedures}

The species studied were "cupiúba" (C-30) and "jatobá" (C-40). This choice took into consideration the results of surveys ${ }^{18}$ which indicated that the C-30 and C-40 classes were most widely employed for sawn dicotyledon wood. The pieces were dried in the open air and humidity controlled by verifying the differences in mass of small samples taken from the planks. These differences were attributed to the water loss of the samples, which resulted in alterations of the wood's humidity content.

Tests were carried out to evaluate the following physical and mechanical properties:

Apparent density with a humidity content of $12 \%$ : $\rho_{\text {ap, }, 12 \%}\left(\mathrm{~kg} / \mathrm{m}^{3}\right)$

Modulus of elasticity in static flection: $\mathrm{E}_{\mathrm{M}}(\mathrm{MPa})$;

Modulus of rupture: MOR (MPa);

Coefficient of the stiffness matrix: $\mathrm{C}_{\mathrm{LL}}(\mathrm{MPa})$.

As shown in Fig. 1, four $6 \mathrm{~cm} \times 16 \mathrm{~cm}$ x $260 \mathrm{~cm}$ beams per species were cut from $8 \mathrm{~cm}$ x $40 \mathrm{~cm}$ x $300 \mathrm{~cm}$ planks. The beams were then cut in half ( $1 / 2$ beams), each half being $130 \mathrm{~cm}$ in length, after which they were cut into sixteen $5 \mathrm{~cm} \times 5 \mathrm{~cm} \times 115 \mathrm{~cm}$ rafters.

The beams and $1 / 2$ beams were subjected to static bending tests to obtain their modulus of elasticity to static

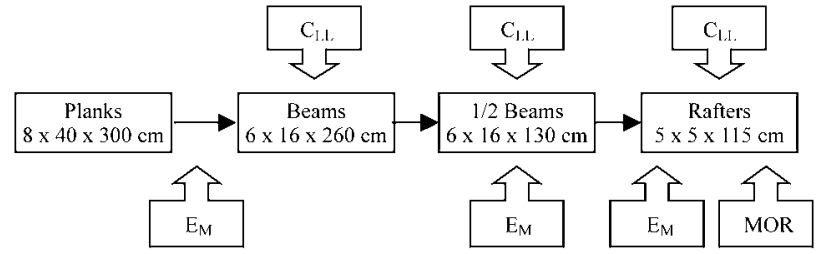

Figure 1. Diagram of the sequence of the experimental stages. flection ( $\left.\mathrm{E}_{\mathrm{M}}\right)$. To simplify the tests, the pieces were placed in the position of least inertia. During the tests, the pieces were subjected to a load applied in mid-span and 8 strain readings were taken. The modulus of elasticity in static bending was then calculated based on the load and strain data.

The bending tests on the rafters were carried out according to the Brazilian NBR 7190/97 code $^{1}$. Half of the pieces, i.e., 8 rafters per specimen, were subjected to bending until rupture occurred in order to determine the modulus of rupture (MOR).

Figure 2 illustrates the SYLVATEST device with $22 \mathrm{kHz}$ transducers that was used to determine the $\mathrm{C}_{\mathrm{LL}}$ coefficient. Medicinal gel was applied to the test specimens to ensure proper contact between the wood and the transducers. This gel improves the transmission of the ultrasonic wave at the interface, preventing interferences in the signal.

Three readings were taken of the wave propagation time for each test specimen: in the center of the sample and on the upper and lower portions, as shown in Fig. 3. The $\mathrm{C}_{\mathrm{LL}}$ coefficient was calculated based on the average of the three

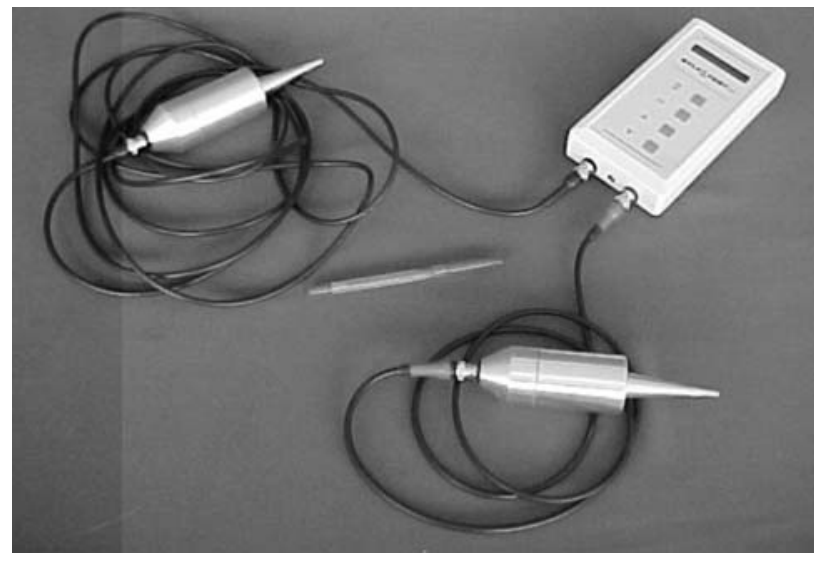

Figure 2. SYLVATEST ultrasound device.

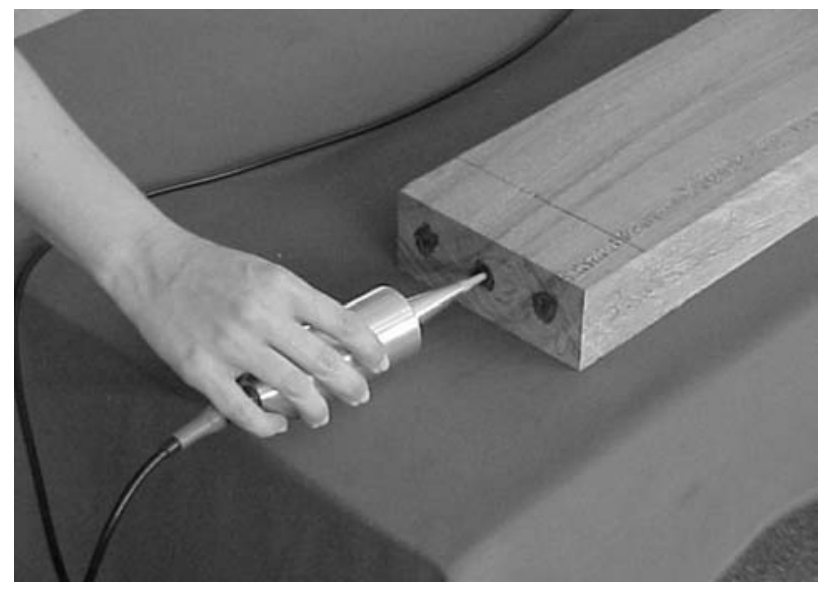

Figure 3. Positioning of the transducers. 
readings and on the density with a humidity content of approximately $12 \%$, according to Eq. 1 . The nondestructive tests preceded the static tests so as to minimize possible variations caused by the strain introduced during the bending test.

\section{Results and Discussion}

Table 1 shows the mean values and the coefficients of variation of the properties determined in the static ( $E_{M}$ and $\mathrm{MOR})$ and dynamic $\left(\mathrm{C}_{\mathrm{LL}}\right)$ tests.

The mean values found for the properties studied here are compatible with those usually found in experiments with dicotyledons.

The coefficients of variation obtained for $\mathrm{C}_{\mathrm{LL}}$ were close to the values found in the literature ${ }^{5}$. These values were lower than the corresponding ones found in the static tests, indicating the lower variability inherent in the nondestructive determination of properties in comparison to the static tests.

The results of the dynamic tests $\left(\mathrm{C}_{\mathrm{LL}}\right)$ were $17 \%$ higher than those of the static ones $\left(\mathrm{E}_{\mathrm{M}}\right)$. The $\mathrm{C}_{\mathrm{LL}}$ term is $22 \%$ higher than the static methods when it is not corrected by Poisson's coefficient ${ }^{2}$.

Shown below is a statistical analysis developed with the purpose of verifying the existence of relations among the variables under study $\left(\mathrm{E}_{\mathrm{M}}, \mathrm{MOR}\right.$ and $\left.\mathrm{C}_{\mathrm{LL}}\right)$ and the levels of significance of the parameters obtained.

Figures 4 and 5 were obtained for these relations.

Table 1. Mean values and coefficients of variation.

\begin{tabular}{lcccccc}
\hline & & $\begin{array}{c}\rho_{\mathrm{ap}, 12 \%}\left(\mathrm{~kg} / \mathrm{m}^{3}\right) \\
(\mathrm{n}=16)\end{array}$ & $\begin{array}{c}\mathrm{E}_{\mathrm{M}}(\mathrm{MPa}) \\
(\mathrm{n}=28)\end{array}$ & $\begin{array}{c}\mathrm{MOR}(\mathrm{MPa}) \\
(\mathrm{n}=8)\end{array}$ & $\begin{array}{c}\mathrm{V}_{\mathrm{LL}}(\mathrm{m} / \mathrm{s}) \\
(\mathrm{n}=28)\end{array}$ & $\begin{array}{c}\mathrm{C}_{\mathrm{LL}}(\mathrm{MPa}) \\
(\mathrm{n}=28)\end{array}$ \\
\hline \multirow{2}{*}{ Cupiúba } & Mean & 827 & 14458 & 110.8 & 4514 & 16876 \\
& $\mathrm{CV}(\%)$ & 1.5 & 12.8 & 9.5 & 3.8 & 7.7 \\
\multirow{2}{*}{ Jatobá } & Mean & 1149 & 17507 & 119.9 & 4279 & 20579 \\
& $\mathrm{CV}(\%)$ & 1.4 & 7.6 & 7.9 & 3.8 & 7.5 \\
\hline
\end{tabular}
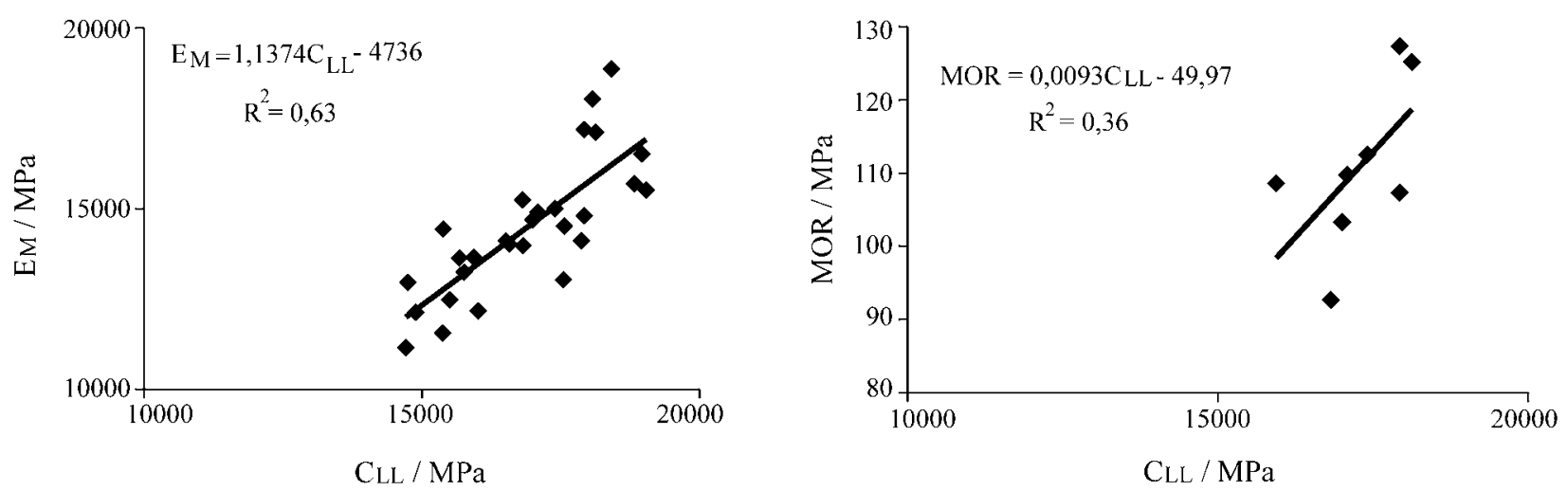

Figure 4. EM and MOR as a function of CLL for the "cupiúba" species.
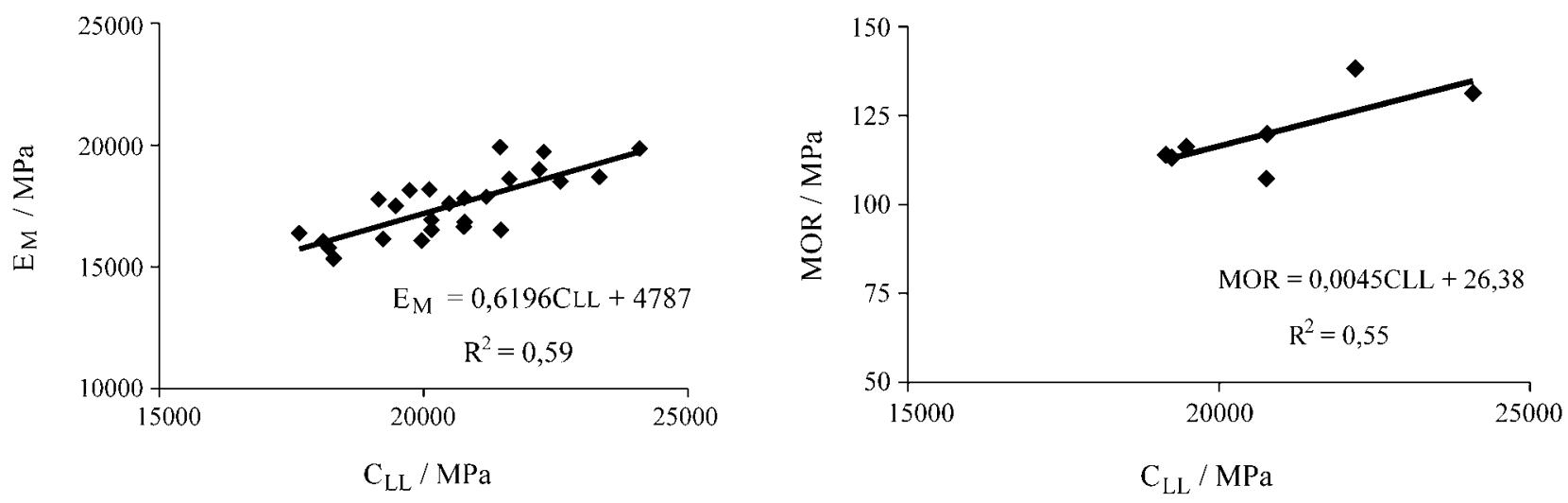

Figure 5. EM and MOR as a function of $C_{L L}$ for the "jatobá" species. 
Table 2. Regressions of the modulus of elasticity in bending and of the modulus of rupture as a function of $\mathrm{C}_{\mathrm{LL}}$

\begin{tabular}{cccc}
\hline & Regression equation & $\mathrm{r}^{2}$ & Significance \\
\hline \multirow{3}{*}{ Cupiúba } & $\mathrm{E}_{\mathrm{M}}=1,1374 \mathrm{C}_{\mathrm{LL}}-4736$ & 0,63 & High Significance \\
& $\mathrm{MOR}=0,0093 \mathrm{C}_{\mathrm{LL}}-49,97$ & 0,36 & No Significance \\
Jatobá & $\mathrm{E}_{\mathrm{M}}=0,6196 \mathrm{C}_{\mathrm{LL}}+4787$ & 0,59 & High Significance \\
& $\mathrm{MOR}=0,0045 \mathrm{C}_{\mathrm{LL}}+26,38$ & 0,55 & Significant \\
\hline
\end{tabular}

\section{Conclusions}

The coefficients of variation obtained for the coefficient of the stiffness matrix $\left(\mathrm{C}_{\mathrm{LL}}\right)$ were lower than those obtained for the modulus of elasticity in static tests $\left(\mathrm{E}_{\mathrm{M}}\right)$, indicating the lesser variability inherent to nondestructive tests on pieces with structural dimensions.

Some of the expressions obtained to associate $\mathrm{C}_{\mathrm{LL}}$ to the properties estimated in static tests presented coefficients that, albeit significant, were inferior to the values found in the literature. One factor that may have contributed to the increased variability of the data obtained and, hence, to the low values of the coefficient of determination $\left(\mathrm{r}^{2}\right)$ recorded, may be associated with the drying process, which is needed so that the wood reaches a humidity content in equilibrium with the air.

The results obtained and analyses carried out, therefore, allow us to conclude that the nondestructive ultrasoundbased method can be employed to obtain reliable evaluations of the mechanical properties of dicotyledons.

\section{Acknowledgements}

The authors thank FAPESP (São Paulo State Research Support Foundation) for its financial support and LaMEM (Laboratory of Wood and Wooden Structures) for its help in the development of this work.

\section{References}

1. Associação Brasileira de Normas Técnicas. - NBR 7190/97 - Projeto de Estruturas de Madeira, Rio de Janeiro, 1997.

2. Bartholomeu, A.; Gonçalves, R. O Uso do Ultra-Som na Determinação de Constante Elástica da Madeira, Anais do $19^{\circ}$ Congresso Nacional de Ensaios NãoDestrutivos, São Paulo, Cd-rom, arquivo digital, 2000.
3. Bodig, J.; Jayne, B.A. Mechanics of Wood and Wood Composites. New York, Van Nostrand Reinhold, 1982.

4. Bucur, V.; Böhnke, I. Ultrasonics, v. 32, n. 5, p. 385-390, 1994.

5. Bucur, V. Acoustics of Wood, New York, CRC Press Inc, 1995.

6. Fengel, D.; Wegener, G. Wood: Chemestry, Ultrastruture, Reactions, Berlin, Walter de Gruyter, 613 p., 1984.

7. Fengel, D. Wood Science and Technology, v. 4, p. 15-35, 1970.

8. Hellmeister, J.C. Sobre a Determinação das Características Físicas da Madeira, São Carlos, 161 p., Tese (Doutorado) - EESC, USP, 1973.

9. Hermann, W. The Chemical Technology of Wood, New York, Academic Press, 1970.

10. Kerr, A.J.; Goring, D.A.I. Cell Chemistry and Technology, v. 9, p. 563-573, 1975.

11. Kollmann, F.E.P.; Cotê, W.A. Principles of Wood Science and Technology, New York, Springer-Verlag, v. 1, 1968.

12. Marchessault, R.H.Actes du Symposium International de Grenoble, Chambéry, p. 287-301, 1964.

13. Oliveira, F.G.R.; Sales, A. Anais $6^{\circ}$ Encontro Brasileiro em Madeiras e em Estruturas de Madeira, São Carlos, Cd-Rom, arquivo digital, 2000.

14. Oliveira, J.T.S. Caracterização da Madeira de Eucalipto para a Construção Civil. São Paulo, 414 p. Tese (Doutorado) - Escola Politécnica, USP, 1997.

15. Philipp, P. Celulose e Papel, São Paulo, IPT / SENAI, v. 1, 559 p, 1988.

16. Preston, R.D. The Physical Biology Of Plant Cell Walls, Chapmam and Hall, p. 169-170, 1962.

17. Rocco Lahr, F.A. Sobre a Determinação de Propriedades de Elasticidade da Madeira, São Carlos, 210-212. Tese (Doutorado) - EESC, USP, 1983.

18. Sales, A. Anais do $12^{\circ}$ Congresso Brasileiro de Ciências e Engenharia de Materiais, Águas de Lindóia, v.1, p. 1334-1337, 1996.

19. Scallan, A.M. Wood Science, v. 6, p. 266-271, 1974.

20. Sjöström, E. Wood Chemistry: Fundamentals and Applications. New York, Academic Press, 222 p., 1981.

21.Zobel, B.J.; Buijtenen, J.P. Wood Variation, New York, Springer-Verlag, 1989.

FAPESP helped in meeting the publication costs of this article 